\title{
Quality of 'Fantasia' Nectarines following Forced-air Heat Treatments for Insect Disinfestation
}

\author{
Michael Lay-Yee and Kellie J. Rose \\ The Horticulture and Food Research Institute of New Zealand(HortResearch), \\ Mount Albert Research Centre, Private Bag 92169, Auckland, New Zealand
}

Additional index words. Prunus persica var. nectarina, postharvest disinfestation, quarantine, heat treatment

\begin{abstract}
Fantasia' nectarine fruit [Prunus persica (L.) Batsch var. nectarina (Ait.) Maxim.], held at $0 \mathrm{C}$ for $\leq 1$ week following harvest, were forced-air heated either immediately after removal from cold storage or after an overnight pretreatment at $20 \mathrm{C}$. Fruit were heated to 41,43 , or $46 \pm$ IC for 24,36 , or 48 hours. Following treatment, fruit were stored for 3 weeks at $0 \mathrm{C}$, held at $20 \mathrm{C}$ for 1 or 5 days, and then assessed for quality. No significant damage, relative to nonheated controls, was observed in pretreated fruit subjected to $41 \mathrm{C}$ for 24 hours. Nonpretreated fruit given the same treatment showed only a slight increase in damage relative to controls. Higher temperatures and longer treatment times, however, were associated with an increased incidence of fruit damage (scald, internal browning, or decay). Heat treatment was associated with reduction in ethylene production and titratable acidity of the fruit following storage.
\end{abstract}

Nectarines are an important export crop for New Zealand, but they are also host to a number of species classified as quarantine pests in some importing countries. These pests are controlled by methyl bromide fumigation, but this treatment can cause fruit damage (Harman et al., 1990). Also, methyl bromide may be unavailable for use as a fumigant soon; this, along with the worldwide trend away from using chemicals, means that there is a need to develop alternative nonchemical disinfestation treatments for this crop.

Heat treatments have been effective in controlling pests and diseases on various horticultural crops (for review see Couey, 1989), and the potential of forced-air heat treatments for controlling the quarantine pests thrips (McLaren et al., 1991) and mites (Waddell and Birtles, 1992) on nectarines has been reported. Also, some stone-fruit species can tolerate certain heat treatments without damage to the fruit; Kerbel et al. (1985) found that 'Suncrest' peaches. [Prunus persica (L.) Batsch] could tolerate a 40-min dip in 40C water followed by $24 \mathrm{~h}$ in $40 \mathrm{C}$ air. Treatments at $43 \mathrm{C}$, however, resulted in injury to the fruit. Our objective was to test the effects of heated air treatments followed by a storage period (to simulate transport and distribution) on the quality of 'Fantasia' nectarines.

\footnotetext{
Received for publication 8 Mar. 1993. Accepted for publication 20 Nov. 1993. The research was funded in part by the New Zealand Fruit Growers Federation. We thank Anne Gunson and John Maindonald for assistance with statistical analysis of data. The cost of publishing this paper was defrayed in part by the payment of page charges, Under postal regulations, this paper therefore must be hereby marked advertisement solely to indicate this fact.
}

\section{Materials and Methods}

A commercial orchard in Hawkes Bay, New Zealand, provided our 'Fantasia' nectarine fruit from a midseason harvest. Fruit were packed in plastic pocket packs inside singlelayer cardboard trays and transported overnight to Auckland, New Zealand, by truck under refrigeration set at $0 \mathrm{C}$. Average fruit flesh firmness, soluble solids concentration (SSC), and flesh color were determined on a 20-fruit sample when it arrived in Auckland. Fruit flesh firmness was measured on two adjacent sides of the fruit (suture and cheek) using an Effegi fruit tester with a 7.9-mm tip (Effegi, Alfonsine, Italy), after an $\approx 2$-mmthick layer of skin was removed at the equator. SSC of juice squeezed from wedges of tissue cut longitudinally from two sides of the fruit was measured using an Atago hand-held refractometer (Atago Co., Tokyo). Internal pericarp color was measured at the equator of cut fruit using a chroma meter with a D65 light source (11 Reflectance; Minolta Camera Co., Osaka, Japan), and recorded using the $\mathrm{L}^{*}, \mathrm{a}^{*}$, $b^{*}$ color space (CIELAB); L* indicates lightness, $\mathrm{a}^{*}$ indicates hue on a green $(-)$ to red $(+)$ axis, and $b^{*}$ indicates hue on a blue $(-)$ to yellow (+) axis. The initial fruit characteristics (mean $+\mathrm{SE})$ were as follows: flesh firmness $(\mathrm{N})=49 \pm 2.8 ; \operatorname{SSC}(\%)=11.5 \pm 0.3$; and flesh color $\mathrm{L}^{*}=71.2 \pm 0.8, \mathrm{a}^{*}=0.5 \pm 0.9, \mathrm{~b}^{*}=40.5$ \pm 1.0. Fruit were held for $\leq 1$ week at $0 \mathrm{C}$ pending treatment.

Heat treatment was performed in a computer-controlled, experimental, forced-air heat unit (HortResearch, Auckland) (external dimensions were $2.4 \mathrm{~m}$ long $\times 1.2 \mathrm{~m}$ wide $\times 1.2$ $\mathrm{m}$ high), which provided four temperature zones for heat treatment. Air, heated by four 2$\mathrm{kW}$ heater elements, was dispersed by a plenum and forced past fruit at $\approx 0.7 \mathrm{~m} \cdot \mathrm{s}^{-1}$. We set and maintained humidity within the unit using two humidifiers (Defensor 505; Defensor AG, Pfaffikon, Switzerland) regulated by a Hygrostate controller (HYG 3501; Eberle $\mathrm{GmbH}$, Numberg, Germany). A lap-top computer (T1200HB; Toshiba Corp., Tokyo) was programmed to control the heating rate to reach predetermined target temperatures, fan speed, and humidity and to record the temperature of the air and the center of selected fruit [PT 100 thermistors; Radio Spares Components, Auckland (accuracy $\pm 0.1 \mathrm{C}$ )] and relative humidity [Philips sensor; Philips, Eindhoven, The Netherlands (accuracy $\pm 3.5 \%)$ ] at 5-min intervals. Temperature control was provided by a proportional and integral controller (HortResearch Technical Services, Auckland).

Fruit, kept in the trays but with the lids removed, were either heated immediately after removal from cold storage or after an overnight pretreatment period at $20 \mathrm{C}$, which brought fruit flesh temperature to $\approx 20 \mathrm{C}$. Fruit were heated to a flesh temperature of 41,43 , or $46 \pm 1 \mathrm{C}$ for 24,36 , or $48 \mathrm{~h}$. Treatment times were measured when heating commenced Fruit reached treatment temperature within 3 to $4 \mathrm{~h}$ and were subsampled from the unit after the appropriate treatment duration. Relative humidity during heat treatment was maintained at $60 \% \pm 5 \%$. Fruit were weighed before and after exposure to heat to determine weight loss associated with the heat treatment and then stored at $0 \mathrm{C}$ for 3 weeks. Controls $(0 \mathrm{~h}$ heat treatment) were kept at $0 \mathrm{C}$ throughout and held in cold storage for the same periods as heat-treated fruit.

Following cold storage, fruit were held at $20 \mathrm{C}$ for 1 or 5 days and examined for external and internal disorders and decay. Fruit with no disorders or decay were designated as sound. Fruit flesh firmness, SSC, and internal pericarp color were measured on each individual fruit as previously described. Acid content of fruit pulp from a composite sample was assessed by titration with $0.1 \mathrm{~N} \mathrm{NaOH}$ to $\mathrm{pH} 8.1$ and expressed as percent citric acid equivalents. Fruit mealiness was estimated by measuring the free juice content of flesh samples. One-gram plugs of tissue were macerated then centrifuged at $9000 \times g$ in a bench-top microfuge (Heraeus Biofuge 13; Heraeus Sepatech $\mathrm{GmbH}$, Osterode, Germany), and the ratio of free juice to total tissue weight was calculated (Lill and Van Der Mespel, 1988). Free juice content was determined only on fruit stored for 3 weeks after heat treatment and held for 5 days at 20C.

Ethyleneproductionrates after storage were determined daily (for $\leq 14$ days) on three replicate fruit for each treatment. Individual fruit were placed in 1-liter plastic containers at 20C. Containers were flushed with air, then sealed for $1 \mathrm{~h}$ each day with a lid containing a rubber septum. After $1 \mathrm{~h}$, a 1-ml gas sample was withdrawn with a syringe and injected into a gas chromatography (Philips PU4500; Pye Unicam, Cambridge, U. K.) fitted with an activated alumina column and a flame ionization detector. After sampling, the lid was removed and the container reflushed with air. 
The design was a $2 \times 3 \times 4 \times 2$ factorial with the four factors as follows: no pretreatment or pretreatment at $20 \mathrm{C}$ overnight, level of heat treatment $(41,43$, or $46 \mathrm{C})$, duration of heat treatment $(\mathrm{O}, 24,36$, or $48 \mathrm{~h})$, and time at $20 \mathrm{C}$ after 3 weeks in cold storage ( 1 or 5 days). Each treatment, consisting of 10 fruit, was replicated three times by separate heat unit runs. We analyzed the results using a miltifactorial analysis of variance. For analysis, percent data was transformed using a logit transformation.

\section{Results and Discussion}

Fruit weight loss, determined immediately following heat treatment, increased with increasing temperature and increasing treatment length $(P \leq 0.001)$. There was no difference in weight loss between nonpretreated and pretreated fruit. With increasing treatment duration from 24 to $48 \mathrm{~h}$, average weight loss increased from $2.7 \%$ to $6.6 \%, 3.6 \%$ to $9.3 \$ 70$, and $6.3 \%$ to $12.2 \%$ for the 41,43 , and $46 \mathrm{C}$ treatments, respectively. Weight remained unchanged in nontreated fruit kept in cold storage during treatment.

The percentage of sound fruit observed with overnight pretreated fruit subjected to $41 \mathrm{C}$ for $24 \mathrm{~h}$, was similar to that in nonheated controls (Table 1). Nonpretreated fruit given the same heat treatment showed only a slight decrease in the percentage of sound fruit relative to controls. All other treatments were associated with increased amounts of fruit damage. In general, the percentage of sound fruit decreased with increasing temperature and length of treatment. Samples assessed after 1 day at 20C had a higher percentage of sound fruit than those assessed after 5 days.

The effect of a 20C overnight pretreatment on response to heat treatment varied with the treatment and assessment time (Table 1). However, at $43 \mathrm{C}$ for $36 \mathrm{~h}$ and all $46 \mathrm{C}$ treatments, the percentage of sound fruit tended to be higher with pretreatment than with no pretreatment. This response could reflect the smaller initial temperature differential experienced by pretreated fruit relative to those not pretreated when subjected to heat treatment, or it may relate to the ripeness of fruit before treatment or to some physiological change in the fruit during pretreatment at 20C. Fruit given a $20 \mathrm{C}$ pretreatment before heating presumably would be slightly riper than those treated directly after cold storage. Further studies are required to elucidate the effect of cold storage on response of nectarines to heat treatment. Preconditioning treatments have been shown to increase thermotolerance of certain crops, e.g., cucumber (Cumis sativus L.) (Chan and Linse, 1989) and papaya (Carica papaya L.) (Paull and Chen, 1990); however, the pretreatment temperatures used in these cases were higher $(3242 \mathrm{C})$ than those used in our experiments.

The main disorders associated with heat treatment were scald (external browning) and internal browning. Overall, the incidence of scald increased with increasing temperature and length of treatment, and internal browning increased in incidence with increasing treatment duration (Table 1). These trends, however, were absent with fruit from the $46 \mathrm{C}$ treatment held for 5 days at 20C. With these

Table 1. Percentage and logit transformation (in brackets) of sound 'Fantasia' nectarines and fruit with scald or internal browning following heat treatment. Fruit were either not pretreated or pretreated at $20 \mathrm{C}$ overnight; then heat-treated to a pulp temperature of 41,43 , or $46 \mathrm{C}$ for $0,24,36$, or $48 \mathrm{~h}$; and stored for 3 weeks at $0 \mathrm{C}$ followed by 1 or 5 days at $20 \mathrm{C}$.

\begin{tabular}{|c|c|c|c|c|c|c|c|c|c|c|c|}
\hline \multirow[b]{3}{*}{ Pretreated } & \multirow[b]{3}{*}{ Temp $\left({ }^{\circ} \mathrm{C}\right)$} & \multirow[b]{3}{*}{ Time (h) } & \multicolumn{3}{|c|}{ Sound $(\%)^{2}$} & \multicolumn{3}{|c|}{ Scald $(\%)^{x}$} & \multicolumn{3}{|c|}{$\begin{array}{c}\text { Internal } \\
\text { browning }(\%)^{\mathrm{z}}\end{array}$} \\
\hline & & & \multicolumn{6}{|c|}{ Days at $20 \mathrm{C}$} & \multirow[b]{2}{*}{1} & \multirow{2}{*}{\multicolumn{2}{|c|}{5}} \\
\hline & & & & 1 & 5 & & 1 & 5 & & & \\
\hline \multirow[t]{12}{*}{-} & 41 & 0 & 100 & {$[5.2]$} & $100 \quad[5.2]$ & 0 & {$[-5.2]$} & $0[-5.2]$ & $0[-5.2]$ & 0 & {$[-5.2]$} \\
\hline & 41 & 24 & 90 & [2.2] & $97 \quad[3.2]$ & 0 & {$[-5.2]$} & $0[-5.2]$ & $10[-2.2]$ & 0 & {$[-5.2]$} \\
\hline & 41 & 36 & 83 & [1.6] & $90 \quad[2.2]$ & 7 & {$[-2.6]$} & $3[-3,2]$ & $10[-2.2]$ & 3 & {$[-3.2]$} \\
\hline & 41 & 48 & 77 & {$[1.2]$} & $83 \quad[1.6]$ & 13 & {$[-1.8]$} & $13[-1.8]$ & $10[-2.2]$ & 3 & {$[-3.2]$} \\
\hline & 43 & 0 & 100 & {$[5.2]$} & $100 \quad[5.2]$ & 0 & {$[-5.2]$} & $0[-5.2]$ & $0[-5.2]$ & 0 & {$[-5.2]$} \\
\hline & 43 & 24 & 97 & [3.2] & $93 \quad[2.6]$ & 0 & {$[-5.2]$} & $0[-5.2]$ & $0[-5.2]$ & 3 & {$[-3.2]$} \\
\hline & 43 & 36 & 73 & {$[1.0]$} & $67[0.7]$ & 13 & {$[-1.8]$} & $10[-2.2]$ & $17[-1.6]$ & 17 & {$[-1.6]$} \\
\hline & 43 & 48 & 33 & {$[-0.7]$} & $27[-1.0]$ & 47 & {$[-0.1]$} & $43[-0.3]$ & $53 \quad[0.1]$ & 40 & {$[-0.4]$} \\
\hline & 46 & 0 & 100 & {$[5.2]$} & $93[2.6]$ & 0 & {$[-5.2]$} & $0[-5.2]$ & $0[-5.2]$ & 0 & {$[-5.2]$} \\
\hline & 46 & 24 & 47 & {$[-0.1]$} & $23[-1.2]$ & 57 & {$[0.3]$} & $37[-0.5]$ & $33[-0.7]$ & 3 & {$[-3.2]$} \\
\hline & 46 & 36 & 10 & {$[-2.2]$} & $0[-5.2]$ & 83 & {$[1.6]$} & $30[-0.8]$ & $63 \quad[0.5]$ & 3 & {$[-3.2]$} \\
\hline & 46 & 48 & 0 & {$[-5.2]$} & $0[-5.2]$ & 83 & {$[1.6]$} & $7[-2.6]$ & $90 \quad[2.2]$ & 3 & {$[-3.2]$} \\
\hline \multirow[t]{12}{*}{+} & 41 & 0 & 100 & {$[5.2]$} & $90 \quad[2.2]$ & 0 & {$[-5.2]$} & $0[-5.2]$ & $0[-5.2]$ & 3 & {$[-3.2]$} \\
\hline & 41 & 24 & 100 & {$[5.2]$} & $93[2.6]$ & 0 & {$[-5.2]$} & $0[-5.2]$ & $0[-5.2]$ & 7 & {$[-2.6]$} \\
\hline & 41 & 36 & 97 & [3.2] & $83 \quad[1.6]$ & 0 & {$[-5.2]$} & $0[-5.2]$ & $3[-3.2]$ & 10 & {$[-2.2]$} \\
\hline & 41 & 48 & 93 & {$[2.6]$} & $80 \quad[1.4]$ & 3 & {$[-3.2]$} & $0[-5.2]$ & $3[-3.2]$ & 20 & {$[-1.4]$} \\
\hline & 43 & 0 & 100 & {$[5.2]$} & $100 \quad[5.2]$ & 0 & {$[-5.2]$} & $0[-5.2]$ & $0[-5.2]$ & 0 & {$[-5.2]$} \\
\hline & 43 & 24 & 97 & {$[3.2]$} & $87 \quad[1.8]$ & 0 & {$[-5.2]$} & $0[-5.2]$ & $3[-3.2]$ & 7 & {$[-2,6]$} \\
\hline & 43 & 36 & 97 & {$[3.2]$} & $73 \quad[1.0]$ & 3 & {$[-3.2]$} & $7[-2.6]$ & $0[-5.2]$ & 27 & {$[-1.0]$} \\
\hline & 43 & 48 & 57 & {$[0.3]$} & $7[-2.6]$ & 3 & {$[-3.2]$} & $63[0.5]$ & $37[-0.5]$ & 67 & {$[0.7]$} \\
\hline & 46 & 0 & 100 & [5.2] & $100 \quad[5.2]$ & 0 & {$[-5.2]$} & $0[-5.2]$ & $0[-5.2]$ & 0 & {$[-5.2]$} \\
\hline & 46 & 24 & 63 & {$[0.5]$} & $40[-0.4]$ & 33 & {$[-0.7]$} & $40[-0.4]$ & $20[-1.4]$ & 23 & {$[-1.2\}$} \\
\hline & 46 & 36 & 27 & {$[-1.0]$} & $13[-1.8]$ & 57 & {$[0.3]$} & $43[-0.3]$ & $47[-0.1]$ & 50 & {$[0.0]$} \\
\hline & 46 & 48 & 3 & {$[-3.2]$} & $3[-3.2]$ & 73 & {$[1.0]$} & $27[-1.0]$ & $73 \quad[1.0]$ & 30 & {$[-0.8]$} \\
\hline \multicolumn{12}{|l|}{ Max. SED } \\
\hline & raction) & & & & & & & & & & \\
\hline \multicolumn{12}{|c|}{ Significance } \\
\hline \multicolumn{3}{|c|}{ Pretreatment } & \multicolumn{3}{|c|}{ NS } & \multicolumn{3}{|c|}{ NS } & \multicolumn{3}{|c|}{ NS } \\
\hline \multicolumn{3}{|l|}{ Temp } & \multicolumn{3}{|c|}{$* * *$} & \multicolumn{3}{|c|}{$* * *$} & \multicolumn{3}{|c|}{ NS } \\
\hline $\mathrm{L}$ & & & \multicolumn{3}{|c|}{$* * *$} & \multicolumn{3}{|c|}{$* * *$} & & & \\
\hline$Q$ & & & & & & & & & & & \\
\hline Time & & & & & & & & & & & \\
\hline $\mathrm{L}$ & & & & & & & & & & & \\
\hline$Q$ & & & & & & & & & & & \\
\hline Assessmen & & & & & & & & & & & \\
\hline Temp $>$ & & & & & & & & & & & \\
\hline $\mathrm{L} \times \mathrm{L}$ & & & & & & & & & & & \\
\hline Deviati & & & & & & & & & & & \\
\hline
\end{tabular}

${ }^{2}$ Mean of three replicates of 10 fruit.

$\mathrm{y}_{\mathrm{L}}=$ linear; $\mathrm{Q}=$ quadratic.

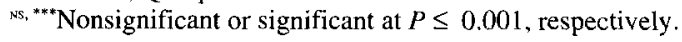


fruit, decay may have masked the presence of the disorders, thus resulting in lower scores (Table 2). Scald was absent in nonheated control fruit. Internal browning was found in only one nonheated control sample, which was associated with the pretreated $41 \mathrm{C}$ fruit.

The incidence of decay was higher in fruit assessed after 5 days at $20 \mathrm{C}$ than in those assessed after 1 day (Table 2). Heat-treated fruit had a higher incidence of rot than nonheated controls, and the percentage of fruit with rot increased with increasing temperature. A high incidence of decay was observed in the 46C treatment. Although certain heat treatments have been shown to be effective in controlling postharvest diseases on various crops (Couey, 1989), enhancement of susceptibility to decay by heat treatment has previously been observed in peaches (Phillips and Austin, 1982; Smith and Anderson, 1975). Decay organisms invading areas injured by the treatment may cause this phenomenon.

Table 2. Percentage and logit transformation (in brackets) of 'Fantasia' nectarines with decay following treatment. Fruit were either not pretreatedorpretreatedat20Covernight; then heattreatedtoapulp temperature of 41,43 , or $46 \mathrm{C}$ for 024,36 , or $48 \mathrm{~h}$; and stored for 3 weeks at $0 \mathrm{C}$ followed by 1 or 5 days at $20 \mathrm{C}$.

\begin{tabular}{|c|c|c|c|c|c|}
\hline \multirow[b]{3}{*}{ Pretreated } & \multirow{3}{*}{$\begin{array}{l}\text { Temp } \\
\left({ }^{\circ} \mathrm{C}\right)\end{array}$} & \multirow{3}{*}{$\begin{array}{c}\text { Time } \\
\text { (h) }\end{array}$} & \multicolumn{3}{|c|}{ Decay $(\%)^{z}$} \\
\hline & & & \multicolumn{3}{|c|}{ Days at $20 \mathrm{C}$} \\
\hline & & & 1 & & 5 \\
\hline \multirow[t]{12}{*}{-} & 41 & 0 & $0[-5.2]$ & 0 & {$[-5.2]$} \\
\hline & 41 & 24 & $0[-5.2]$ & 3 & {$[-3.2]$} \\
\hline & 41 & 36 & $0[-5.2]$ & 3 & {$[-3.2]$} \\
\hline & 41 & 48 & $3[-3.2]$ & 3 & {$[-3.2]$} \\
\hline & 43 & 0 & $0[-5.2]$ & 0 & {$[-5.2]$} \\
\hline & 43 & 24 & $3[-3.2]$ & 3 & {$[-3.2]$} \\
\hline & 43 & 36 & $0[-5.2]$ & 17 & {$[-1.6]$} \\
\hline & 43 & 48 & $0[-5,2]$ & 30 & {$[-0.8]$} \\
\hline & 46 & 0 & $0[-5.2]$ & 7 & {$[-2.6]$} \\
\hline & 46 & 24 & $10[-2.2]$ & 40 & {$[-0.4]$} \\
\hline & 46 & 36 & $7[-2.6]$ & 63 & {$[0.5]$} \\
\hline & 46 & 48 & $7[-2.6]$ & 90 & [2.2] \\
\hline \multirow[t]{12}{*}{+} & 41 & 0 & $0[-5.2]$ & 7 & {$[-2.6]$} \\
\hline & 41 & 24 & $0[-5.2]$ & 7 & {$[-2.6]$} \\
\hline & 41 & 36 & $0[-5,2]$ & 7 & {$[-2.6]$} \\
\hline & 41 & 48 & $0[-5.2]$ & 3 & {$[-3.2]$} \\
\hline & 43 & 0 & $0[-5.2]$ & 0 & {$[-5.2]$} \\
\hline & 43 & 24 & $0[-5.2]$ & 7 & {$[-2.6]$} \\
\hline & 43 & 36 & $0[-5.2]$ & 3 & {$[-3.2]$} \\
\hline & 43 & 48 & $3[-3.2]$ & 43 & {$[-0.3]$} \\
\hline & 46 & 0 & $0[-5.2]$ & 0 & {$[-5.2]$} \\
\hline & 46 & 24 & $10[-2.2]$ & 33 & {$[-0.7]$} \\
\hline & 46 & 36 & $7[-2.6]$ & 77 & [1.2] \\
\hline & 46 & 48 & $3[-3.2]$ & 40 & {$[-0.4]$} \\
\hline
\end{tabular}

Max. SED

(two-way interaction)

Significance $^{y}$

Pretreatment

Temp

L

Q

Time

L

Q
Assessment

Temp $\times$ time

$\mathrm{L} \times \mathrm{L}$

Deviations

$[0.7]$

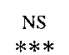

NS

***

NS

$* * *$

NS

$* * *$

NS

vs

${ }^{2}$ Mean of three replicates of 10 fruit.

${ }^{{ }^{2}} \mathrm{~L}=$ linear; $\mathrm{Q}=$ quadratic.

Ns. $* * * * *$ Nonsignificant or significant at $P \leq 0.01$ or 0.001 , respectively.
After storage, flesh firmness was higher in fruit assessed after 1 day at 20C than in those assessed after 5 days (Table 3 ). At 5 days, fruit subjected to $46 \mathrm{C}$ treatments tended to have a higher flesh firmness than those treated at 41 and $43 \mathrm{C}$ and control fruit. The fruit from these 46C treatments were "rubbery," and this characteristic appeared to result in a higher flesh firmness. There was no significant difference in firmness between nonpretreated and pretreated fruit.

The flesh of fruit assessed after 5 days at $20 \mathrm{C}$ was redder (higher $\mathrm{a}^{*}$ values) than that of fruit assessed after 1 day at 20C (Table 3). The flesh of fruit from the $41 \mathrm{C}$ treatment tended to be redder than that of fruit from the 43 and 46C treatments. There was no significant difference in $\mathrm{a}^{*}$ values between nonpretreated and pretreated fruit.

Average SSC in fruit following storage was $\approx 11.7 \%$, and there was no significant difference between treated fruit and the con- trols at $P \leq 0.01$. Titratable acidity levels in heat-treated fruit were lower than those in nonheated control fruit (Table 3). Pretreated fruit had a slightly lower titratable acidity than nonpretreated fruit. There was no difference in titratable acidity between fruit from the three temperatures tested; however, there was a significant decrease in titratable acidity with increasing" length of treatment.

Free juice content of fruit assessed after 5 days at 20C decreased as length of treatment increased from 24 to $48 \mathrm{~h}$ (Table 3 ). There was no significant difference in free juice content between nonpretreated and pretreated fruit or between different temperature treatments.

Maximum ethylene production by stored nectarines after treatment at 41 and $43 \mathrm{C}$, with or without pretreatment, was lower than that of control fruit (Fig. 1). Fruit ethylene production was inhibited almost completely by $46 \mathrm{C}$. The inhibition of fruit ethylene production by heat treatment has been observed by other

Table 3. Flesh firmness, flesh redness (CIELAB a* value), and percent titratable acidity (TA) and free juice of 'Fantasia' nectarines following heat treatment. Fruit were either not pretreated or pretreated at $20 \mathrm{C}$ overnight; then heat-treated to a pulp temperature of 41,43 , or $46 \mathrm{C}$ for $0,24,36$, or $48 \mathrm{~h}$; and stored for 3 weeks at $0 \mathrm{C}$ followed by 1 or 5 days at $20 \mathrm{C}$.

\begin{tabular}{|c|c|c|c|c|c|c|c|c|c|}
\hline \multirow[b]{3}{*}{ Pretreated } & \multirow{3}{*}{$\begin{array}{l}\text { Temp } \\
\left({ }^{\circ} \mathrm{C}\right)\end{array}$} & \multirow{3}{*}{$\begin{array}{c}\text { Time } \\
\text { (h) }\end{array}$} & \multirow{2}{*}{\multicolumn{2}{|c|}{ Flesh firmness $(\mathrm{N})^{7}$}} & \multirow{2}{*}{\multicolumn{2}{|c|}{$\begin{array}{l}\text { a* Value }^{2, y} \\
\text { Days at 20C }\end{array}$}} & \multirow{2}{*}{\multicolumn{2}{|c|}{ TA $(\%)^{x}$}} & \multirow{3}{*}{$\frac{\text { Free juice }^{2}}{5}$} \\
\hline & & & & & & & & & \\
\hline & & & 1 & 5 & 1 & 5 & 1 & 5 & \\
\hline \multirow[t]{12}{*}{-} & 41 & 0 & 56 & 12 & 1.7 & 4.5 & 7 & 7 & 40 \\
\hline & 41 & 24 & 43 & 6 & 1.9 & 6.1 & 5 & 6 & 41 \\
\hline & 41 & 36 & 43 & 7 & 2.1 & 11.0 & 5 & 5 & 30 \\
\hline & 41 & 48 & 49 & 6 & 4.3 & 16.7 & 5 & 5 & 22 \\
\hline & 43 & 0 & 50 & 10 & 1.6 & 4.6 & 6 & 7 & 37 \\
\hline & 43 & 24 & 47 & 6 & 2.6 & 6.7 & 5 & 5 & 39 \\
\hline & 43 & 36 & 45 & 8 & 3.5 & 5.1 & 4 & 5 & 27 \\
\hline & 43 & 48 & 46 & 13 & 2.7 & 5.0 & 5 & 5 & 21 \\
\hline & 46 & 0 & 46 & 9 & 2.2 & 5.2 & 7 & 7 & 40 \\
\hline & 46 & 24 & 48 & 10 & 0.5 & 5.8 & 6 & 5 & 37 \\
\hline & 46 & 36 & 41 & 21 & 2.2 & 5.1 & 5 & 5 & 18 \\
\hline & 46 & 48 & 40 & 18 & 2.9 & 1.4 & 5 & 4 & 16 \\
\hline \multirow[t]{12}{*}{+} & 41 & 0 & 50 & 17 & 3.6 & 6.1 & 6 & 6 & 26 \\
\hline & 41 & 24 & 47 & 9 & 3.0 & 6.3 & 5 & 5 & 42 \\
\hline & 41 & 36 & 46 & 12 & 3.5 & 10.3 & 5 & 5 & 24 \\
\hline & 41 & 48 & 42 & 13 & 5.1 & 11.8 & 4 & 5 & 7 \\
\hline & 43 & 0 & 42 & 15 & 3.9 & 6.1 & 6 & 6 & 25 \\
\hline & 43 & 24 & 42 & 10 & 3.4 & 8.8 & 5 & 4 & 36 \\
\hline & 43 & 36 & 58 & 17 & 2.1 & 6.0 & 5 & 5 & 30 \\
\hline & 43 & 48 & 42 & 18 & 2.1 & 2.8 & 4 & 4 & 19 \\
\hline & 46 & 0 & 42 & 15 & 4.2 & 6.5 & 7 & 6 & 27 \\
\hline & 46 & 24 & 51 & 22 & 2.9 & 2.3 & 5 & 4 & 27 \\
\hline & 46 & 36 & 49 & 34 & 3.7 & 1.7 & 4 & 4 & 22 \\
\hline & 46 & 48 & 45 & 43 & 3.1 & 2.4 & 4 & 4 & 15 \\
\hline \multicolumn{3}{|c|}{$\begin{array}{l}\text { Max SED } \\
\text { (two-way interaction) }\end{array}$} & & & & .06 & 0.22 & 0.21 & 4.15 \\
\hline \multicolumn{10}{|c|}{ Significance ${ }^{w}$} \\
\hline \multicolumn{3}{|c|}{ Pretreatment } & \multicolumn{2}{|c|}{ NS } & \multicolumn{2}{|c|}{ NS } & \multicolumn{2}{|c|}{$* * *$} & NS \\
\hline \multicolumn{3}{|l|}{ Temp } & \multicolumn{2}{|c|}{ Ns } & \multicolumn{2}{|c|}{$* *$} & \multicolumn{2}{|c|}{ NS } & NS \\
\hline $\mathrm{L}$ & & & \multicolumn{2}{|c|}{ NS } & \multicolumn{2}{|c|}{$* * *$} & \multicolumn{2}{|c|}{ NS } & NS \\
\hline Q & & & \multicolumn{2}{|c|}{ NS } & \multicolumn{2}{|c|}{ NS } & & & NS \\
\hline Time & & & & & & NS & & & $* * *$ \\
\hline $\mathrm{L}$ & & & & & & NS & & & $* * *$ \\
\hline $\mathrm{Q}$ & & & & & & NS & & & $* *$ \\
\hline Assessm & & & & & & $* *$ & & & --- \\
\hline Temp & time & & & & & NS & & & NS \\
\hline $\mathrm{L} \times \mathrm{L}$ & & & & & & ** & & & NS \\
\hline Deviat & & & & & & NS & & & NS \\
\hline
\end{tabular}

${ }^{2}$ Mean of three replicates of 10 fruit.

'Measured using a Minolta chroma meter II reflectance in CIELAB; $\mathrm{a}^{*}$ indicates hue on a green (-) to red $(+)$ axis.

${ }^{x}$ Mean of three replicate composite samples; expressed as citric acid equivalents.

${ }^{w} \mathrm{~L}=$ linear; $\mathrm{Q}=$ quadratic.

ws. **.*** Nonsignificant or significant at $P \leq 0.01$ or 0.001 , respectively. 


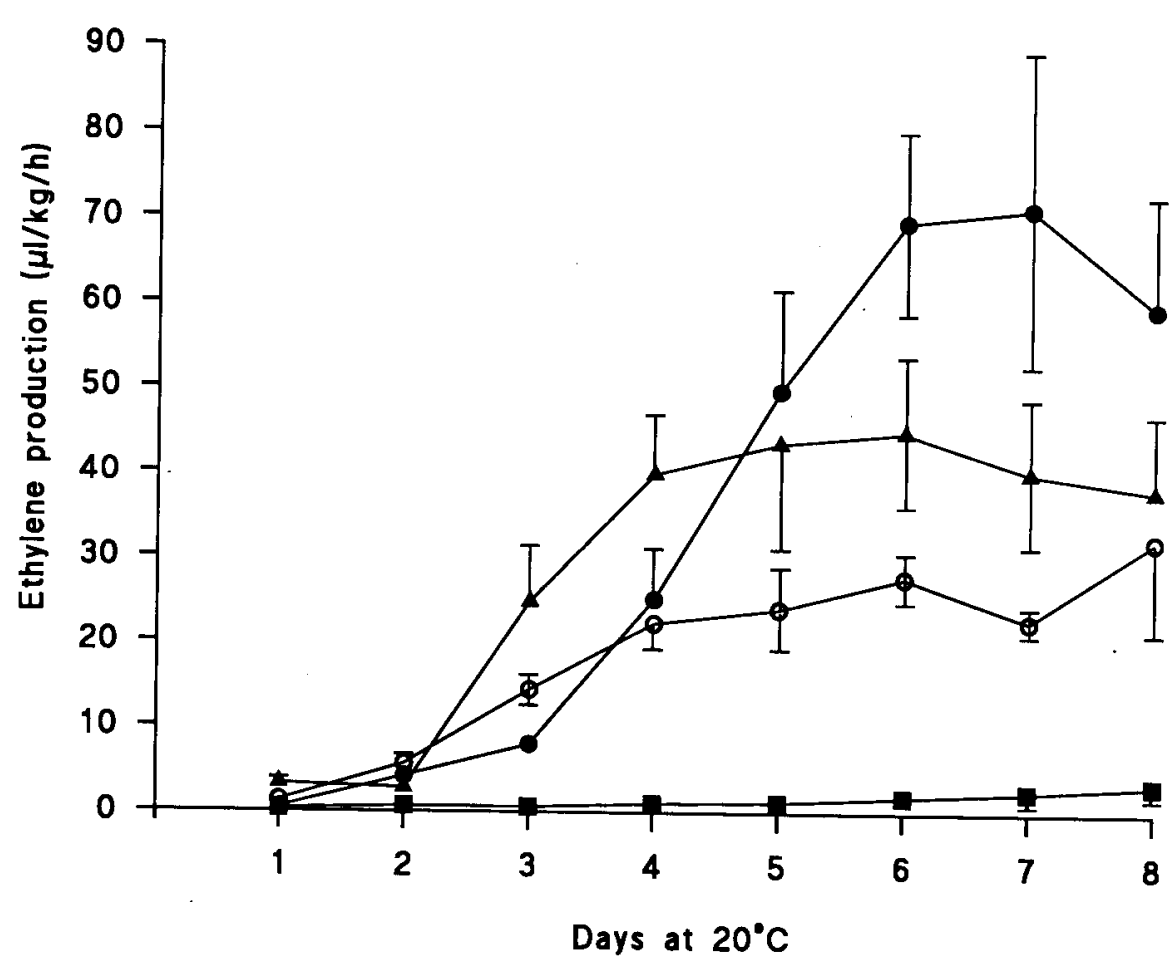

Fig. 1. Ethylene production by 'Fantasia' nectarines held at $20 \mathrm{C}$ following heat treatment. Fruit, removed from $0 \mathrm{C}$ storage, were forced-air heated directly to a pulp temperature of $41 \mathrm{C}(\boldsymbol{\Delta}), 43 \mathrm{C}(\mathrm{O})$ or $46 \mathrm{C}(\mathbf{a})$ and held for $24 \mathrm{~h}$ followed by 3 weeks storage at $0 \mathrm{C}$. Control fruit (O) were held at $0 \mathrm{C}$ throughout treatment. Each point is the mean of measurements from three fruit; vertical bars represent SE.

researchers; although in those cases, measurements were made on fruit immediately after heat treatment as opposed to after a period in cold storage following treatment. For example, Anthony et al. (1989) reported that moist-air, heat treatment of nectarines at $52 \mathrm{C}$ for 15,30 , or 45 min inhibited fruit ethylene production. Lurie and Klein (1990) working on apple (Malus domestica Borkh.) fruit found a reversible inhibition of ethylene production afteran apparently nondamaging treatment of $38 \mathrm{C}$ for 4 days. In avocado (Persea americana Mill.), a temperature of $40 \mathrm{C}$ for 2 days resulted in a similar response (Eaks, 1978). Ethyleneforming enzyme activity in apples, papaya, and cucumber has been shown to be inhibited by heat treatment (Chan, 1986a, 1986b; Klein, 1989).
In summary, our results suggest that a treatment of $41 \mathrm{C}$ for $\leq 24 \mathrm{~h}$ may be within the tolerance limits of 'Fantasia' nectarine fruit, although further studies are required to determine the effects of fruit maturity and differing growing conditions and postharvest pretreatment environments on fruit response. thrips obscuratus (Crawford), a quarantine pest found on New Zealand nectarines, can be controlled by a heated-air treatment of 38-40C for $12 \mathrm{~h}$ (McLaren et al., 1991). Our results, therefore, indicate that there is potential for a heated-air treatment to be an effective disinfestation treatment for 'Fantasia' nectarines.

\section{Literature Cited}

Anthony, B.R.,D.J.Phillips,S.Badr,andY.Aharoni. 1989. Decay control and quality maintenance after moist air heat treatment of individually plastic-wrappednectarines.J. Amer. Soc. Hort. Sci.114:946-949.

Chan, H.T. 1986a. Effects of heat treatment on the ethyleneformingenzymeinpapaya.J. Food Sci. 51:581-583.

Chan,H.T.1986b.Heatinactivationof the ethyleneforming enzyme system in cucumbers. J. Food Sci. 51:1491-1493.

Chan, H.T. and E. Linse, 1989. Conditioning cucumbers for quarantine heat treatments. HortScience 24:985-989.

Couey, H.M. 1989. Heat treatment for control of postharvest diseases and insect pests of fruits. HortScience 24:198-202.

Eaks, I. 1978. Ripening, respiration, and ethylene productionof'Hass'avocadofruitsat 20 to $40 \mathrm{C}$. J. Amer. Soc. Hort. Sci. 103:576-578.

Harman, J. E., M. Lay-Yee, D.P. Billing, C.W. Yearsley, and P.J. Jackson. 1990. Effects of methyl bromide fumigation, delayed cooling, and controlled atmosphere storage on the quality of 'Redgold' and 'Fantasia' nectarine fruit. N.Z. J. Crop Hort. Sci. 18:197-203,

Kerbel, E. L., F.G. Mitchell, and G. Meyer. 1985. Effect of postharvest heat treatments for insect controlonthequalityandmarketlife of peaches. Hortscience 20:725-727.

Klein, J.D. 1989. Ethylene biosynthesis in heat treated apples, p. 184-190. In: M. Clijsters, R. de Proft, R. Marcelle, and M. van Pouke (eds.). Biochemicalandphysiologicalaspectsofethylene production in lower and higher plants. Klewer AcademicPress, Dordrecht, The Netherlands.

Lill,R.E.and G.J. Van Der Mespel. 1988. A method formeasuringthejuicecontent of mealy nectarines.Scientia Hort. 36:267-271.

Lurie, S. and J.D. Klein. 1990. Heat treatment of ripeningapples:Differentialeffectson physiology and biochemistry. Physiol. Plant. 78:181-186.

McLaren,G.F.,B.C.Waddell, P.J. Jackson, M. LayYee, J.A. Fraser, and T.A. Batchelor. 1991. Can heatkillthripsonsummerfruit? The Orchardist of N.Z. 64:15.

Paull, R.E. and N.J. Chen. 1990. Heat shock response in field-grown, ripening papaya fruit. J. Amer. Soc. Hort, Sci. 115:623-631.

Phillips, D.J. and R.K. Austin, 1982. Changes in peaches after hot-water treatment. Plant Dis. 66:487488.

Smith, W.L. and R.E. Anderson. 1975. Decay control of peaches and nectarines during and after controlledatmosphereand air storage. J. Amer. Soc. Hort. Sci. 100:84-86.

Waddell, B.C. and D.B. Birtles. 1992. Disinfestation of nectarines of two-spotted mites (Atari: Tetranychidae).N.Z. J. Crop Hort. Sci. 20:229234 
Table 4. Internal browning incidence and fruit quality characteristics of 'Seuri' Chinese pear stored at $0 \mathrm{C}$ for 28 days ( 0 ) or held for 7 days at $20 \mathrm{C}$ before storage at $0 \mathrm{C}$ for 21 days $(20 / 0)$.

\begin{tabular}{|c|c|c|c|c|}
\hline $\begin{array}{l}\text { Harvest } \\
\text { date }\end{array}$ & $\begin{array}{l}\text { Storage } \\
\text { temp. } \\
\left({ }^{\circ} \mathrm{C}\right)\end{array}$ & $\begin{array}{l}\text { Color }^{2} \\
\left(\mathrm{~h}^{\circ}\right)\end{array}$ & $\begin{array}{c}\text { Firmness } \\
(\mathrm{N})\end{array}$ & $\begin{array}{c}\text { Internal } \\
\text { browning } \\
(\%)\end{array}$ \\
\hline \multirow[t]{2}{*}{21 Aug. } & 0 & 97.5 & 58.5 & 0 \\
\hline & $20 / 0$ & 93.4 & 61.7 & 0 \\
\hline \multirow{2}{*}{25 Aug. } & 0 & 98.7 & 61.7 & 0 \\
\hline & $20 / 0$ & 91.4 & 61.7. & 0 \\
\hline \multirow[t]{2}{*}{3 Sept. } & 0 & 97.3 & 58.5 & 0 \\
\hline & $20 / 0$ & 91.9 & 59.0 & 56 \\
\hline \multirow[t]{2}{*}{11 Sept. } & 0 & 93.5 & 58.1 & 94 \\
\hline & $20 / 0$ & 87.3 & 54.0 & 100 \\
\hline \multirow[t]{2}{*}{17 Sept. } & 0 & 90.8 & 54.9 & 100 \\
\hline & $20 / 0$ & 87.7 & 51.8 & 100 \\
\hline \multirow[t]{2}{*}{23 Sept. } & 0 & 90.4 & 59.0 & 94 \\
\hline & $20 / 0$ & 88.0 & 53.6 & 100 \\
\hline \multicolumn{5}{|c|}{ Significance } \\
\hline \multicolumn{2}{|l|}{ Date } & * & $*$ & * \\
\hline \multicolumn{2}{|c|}{ Treatment } & * & NS & *. \\
\hline \multicolumn{2}{|c|}{ Date $\times$ treatment } & * & NS & * \\
\hline
\end{tabular}

${ }^{\mathrm{t}} \mathrm{h}^{\circ}$ (from arctan $\left.\mathrm{b}^{*} / \mathrm{a}^{*}\right)$ is the hue angle $\left(0^{\circ}=\right.$ red-purple, $90^{\circ}=$ yellow, $180^{\circ}=$ bluish-green, $270^{\circ}=$ blue $)$. Values are an average of two measurements on the blossom end of the fruit and two on the cheeks per each of the five replications. Measurements were taken after 1 month of storage.

ws. Nonsignificant or significant at $P \leq 0.05$ within columns using the $\mathrm{F}$ test.

tracting $4 \mathrm{C}$, and summing the resulting values (Johnson and Lakso, 1985). First symptoms of IB were observed after 1 month of storage in 'Ya Li' fruit harvested 3215 degree days (3 Sept.) from full bloom and in 'Seuri' picked 3299 degree days (11 Sept.) from full bloom.

The fruit should be picked when most of the pears on the tree are still green, although a few at the top may begin to develop some light-yellow spots. Fruit picked when the skin month after harvest. Prompt cooling of fruit is recommended as delays in cooling increase the incidence of IB on pears that are beginning to yellow.

We suggest that growers who are having IB problems in Chinese pears keep records of the number of days after full bloom needed for their fruit to start turning light yellow to help is completely yellow will develop IB within 1 them decide when to pick in subsequent years. Fruit size and SSC can be maximized by proper pollination and thinning (Beutel, 1990) rather than delayed harvesting.

\section{Literature Cited}

Beutel, J, 1990. Asian pears, p. 304-308. In: J Janick and J.E. Simon (eds.). Advances in new crops. Timber Press, Portland, Ore.

Crisosto, C., D. Garner, S. Sibbett, and K. Day. 1992. Maturity studies on Asian pear. Central Valley Postharvest Nwsl. 1(2):1-3.

Downs, C. G., C.J. Brady, J. Campbell, and W.B. McGlasson.1991. Normal ripening cultivars of Pyrus serotina are either climacteric or non-climacteric.ScientiaHort.48:2 13-221.

Griggs, W. and B. Iwakiri. 1977. Asian pear varieties in California. Univ. of California DANR Publ. 4068, Oakland

Johnson, R.S. and A.N. Lakso. 1985, Relationships between stem length, leaf area, stem weight, and accumulated growing degree-days in apple shoots. J. Amer. Soc. Hort. Sci. 110:586-590.

Kitamura,T.,T.Iwata,T.Fukushima, Y. Furukawa, andT.Ishaguro.1981.Studieson the maturation physiology and storage of fruit and vegetables. II.Respirationandethyleneproduction in referencetospecies and cultivars of pear fruit. J. Jpn. Soc. Hort. Sci. 49:608-616.

McGuire, R.G. 1992. Reporting of objective color measurements,HortScience 27:1254-1255.

Porritt,S.W.,M.Meheriuk,andP.D. Lindster. 1982. Postharvest disorders of apples and pears. Agr. Canada Publ. 1737/E.

SAS Institute. 1988. SAWSTAT user's guide. Release 6.03 ed. SAS Inst., Cary, N.C. 